\title{
Blue Light Exposure Improving Cognitive Function by Increasing Serum Orexin Level in Shift Working Nurse at Sanglah Central Hospital Denpasar
}

\author{
Anak Agung Ayu Putri Laksmidewi*, Yuliantry Indah Lestari, Ni Putu Ayu Putri Mahadewi, I. Made Oka Adnyana, \\ Anak Agung Bagus Ngurah Nuartha
}

Department of Neurology, Faculty of Medicine, Udayana University, Sanglah Hospital, Denpasar

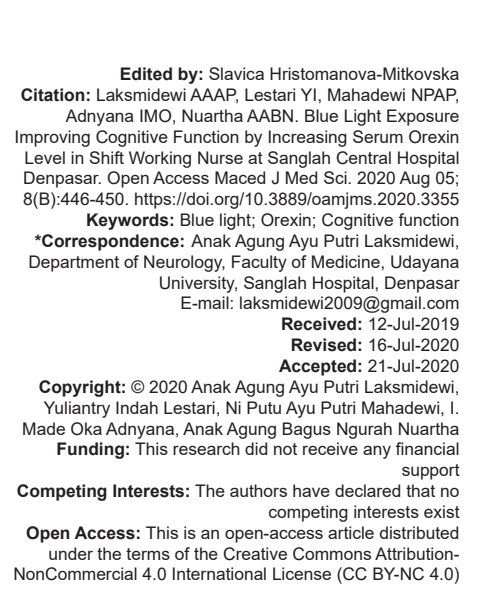

\begin{abstract}
BACKGROUND: Nurses are one of the many jobs that use the shift work system. Nurses work lovingly, requiring high attention when working. Sleep disorders are often experienced by nurses who work shifting outside of normal working hours. Long sleep disorders can cause cognitive function disorders.

AIM: This study aims to determine the effectiveness of exposure to blue light in improving cognitive function and serum orexin levels compared to exposure to white light.

METHODS: An experimental study with a pre-test-post-test control group design. Subjects were divided into treatment groups (exposure to blue light) and the control group (exposure to white light) equally. Both groups assessed cognitive function scores using the MoCA-INA and examined serum orexin levels before and after light exposure.

RESULTS: The mean increase in the cognitive function score of the treatment group $(5.00 ; p<0.001)$ was greater than the control group $(0.417 ; p=0.054)$ and the mean increase in serum orexin levels in the treatment group (1068, $244 ; p<0.001)$ was greater than the control group $(336,706 ; p=0.052)$, the increase in the treatment group was found to be statistically significant.

CONCLUSION: Exposure to blue light before carrying out night shift can increase cognitive function scores 5 times greater and increase serum orexin levels higher than exposure to white light on nurses.
\end{abstract}

\section{Introduction}

Nurses in work must remain vigilant and always full of love but sometimes can experience sleep disorders, especially those working with a rotating system. Disorders of sleep patterns affect circadian rhythms. Humans need sleep which is an active physiological process is needed for restoration and recovery, but the overall level of brain activity is not reduced during sleep.

The rhythm of the human body is regulated by a part of the ventral anterior hypothalamus, the suprachiasmatic nucleus (SCN) located in the third ventricle at the top of the optic chiasm. SCN consists of two pairs of nuclei, namely, dorsomedial shell and ventrolateral core. The efferent fibers from the SCN will trigger nerve and humoral signals that will harmonize the circadian rhythm. The pineal gland in the brain works for a feedback mechanism to regulate $\mathrm{SCN}$, inhibit melatonin production and excite orexin through the retinohypothalamic (TRH) tract and SCN. Lateral hypothalamic area (LHA) has three main neurons, namely, orexin neurons, $\mathrm{MCH}$ neurons, and neurons that contain glutamic acid decarboxylase (GAD) 65. Orexin neurons play a role in awake conditions, whereas GAD 65 and $\mathrm{MCH}$ neurons only play a role during sleep and especially during the rapid eye movement sleep (REMS) [1], [2].

The intensity of bright and dark light accompanied by a number of planned naps is an important factor in circadian rhythms which is a rhythmic biological process that affects 24-h mental, physical, and behavioral conditions that also regulate body temperature, blood pressure, and secretion patterns of the body. Signals from retina will be forwarded to an SCN oscillation system in the hypothalamus through the TRH tract. Giving blue light that has short waves (466-477 nm) at night is known to reduce melatonin levels in the blood and is associated with an increase in attention function and concentration [3], [4], [5]. Orexin is known to be associated with attention function, alertness, and concentration in awake conditions.

Every sleep cycle, someone passes non-rapid eye movement and REM stadiums. During certain stages of sleep, there is an increase in brain oxygen absorption beyond normal when awake. Paradoxal 
sleep is necessary for learning ability and especially considering procedural memory consolidation. Orexin has the ability to affect the body in awake conditions. The orexin system is regulated by oxygenic neurons located laterally in the hypothalamus (lateral hypothalamic area) and the back of the hypothalamus (posterior hypothalamus). These oxygenic neurons also play a role in the wake-up cycle by activating the ascending arousal system, all parts of the cerebral cortex and other structures. Oxygenic neuron activity is also known to affect food intake regulation by increasing NPY neuron activity, stimulating the nucleus tractus solitarius (NTS), and paraventricular nucleus (PVN) which then integrates with peripheral signals, regulates energy balance, food intake, and satiety, stimulates reward systems and regulating abnormal food intake, increasing sympathetic activity and decreasing leptin secretion, and stimulating ghrelin secretion [6].

The quality of work and cognitive function is affected by long-standing sleep disorders. The most common cognitive impairment is attention disorder and reported concentration of $47.3 \%$ [7], [8]. Nurses work with attention and low concentration on the lives of patients treated. Research on 502 shifted nurses, reported $65 \%$ complained of the difficulty of staying awake while working more than $12 \mathrm{~h}$ at night, $20 \%$ stated that they fell asleep at work. Nurses who work more than $12 \mathrm{~h}$ have an error rate that has doubled; this is associated with a low level of attention and concentration that is $27 \%$ made a mistake and $38 \%$ almost made mistakes in their work. The most common are errors in drug administration such as errors regarding the type of drug and drug dosage [9]. Orexin is also called hypocretin that has the ability to affect the body both for attention functions and concentration in conditions awake [1].

\section{Methods}

This study used an experimental design pre-test-post-test control group design with research subjects divided into two groups, namely, the treatment group (giving exposure to blue light) and the control group (giving exposure to white light). The assessment of cognitive function was performed with the MoCA-INA questionnaire. Giving exposure to blue or white light for $30 \mathrm{~min}$ in the nurse locker room and carried out 30 min before the night shift work begins, the subject can carry out activities as usual when getting light exposure. The frequency of giving exposure to blue or white light is 8 times in 30 days. Examination of serum levels and MoCA-INA assessments was carried out before and after treatment.

Bivariate analysis was performed to assess cognitive impairment, including age, gender, education level, and length of work. The hypothesis test used is Chi-square. The significance of this study set is $p<0.05$.

The normality test performed on data on the increasing score and serum levels of both groups using the Shapiro-Wilk test. The hypothesis test used is paired t-test and the level of significance measured with a value of $p<0.01$. Unpaired t-test was carried out to determine the significance or effectiveness between the administration of blue light and white light on increasing cognitive function scores.

\section{Results}

This research was conducted in June-July 2017 at Sanglah Hospital Denpasar. This study used a pre-test-post-test control group design. The subjects of the control group with exposure to white light. Both groups examined serum levels and evaluated cognitive function before and after the administration of light exposure. The basic characteristics of the research are the level of education and length of work. Female gender is more than men in the treatment group $(83.3 \%)$ and controls $(91.7 \%)$. The results of the basic characteristics of the subjects are illustrated in Table 1.

Bivariate statistics for treatment and control groups showed age, sex, education level, and length of work not a risk factor that was statistically significant for the incidence of cognitive dysfunction with each value of $p>0.05$, the results are shown in Table 2 .

Table 1: Basic characteristics of research subjects

\begin{tabular}{lll}
\hline Variable & Groups & \\
\cline { 2 - 3 } & Treatment $(\mathrm{n}=12)$ & Control $(\mathrm{n}=12)$ \\
\hline Mean age (year) & $31.42 \pm 7.271$ & $32.42 \pm 9.090$ \\
Gender (\%) & $10(83.3)$ & $11(91.7)$ \\
$\quad$ Female & $2(16.7)$ & $1(8.3)$ \\
$\quad$ Male & $9(75)$ & $9(75)$ \\
Education (\%) & $3(25)$ & $3(25)$ \\
$\quad$ Diploma & & \\
$\quad$ Bachelor & $4(44.4)$ & $5(55.6)$ \\
Length of working (\%) & $8(53.3)$ & $7(46.7)$ \\
$\quad$ < year & & \\
5-10 year & &
\end{tabular}

The Shapiro-Wilk test showed that the average increase in normal scattered cognitive function scores, then performed a paired t-test, found that the mean increase in MoCA-INA in the treatment group (5.00; $p<0.001)$ was higher than the control group $(0.417 ; p=0.054)$. The results of the analysis are presented in Table 3.

Table 2: Factors affecting cognitive function disorders

\begin{tabular}{|c|c|c|c|}
\hline \multirow[t]{2}{*}{ Variable } & \multicolumn{2}{|l|}{ Groups } & \multirow[t]{2}{*}{ p-value } \\
\hline & Treatment $(n=12)$ & Control $(n=12)$ & \\
\hline Mean age (year) & $31.42 \pm 7.271$ & $32.42 \pm 9.090$ & 0.615 \\
\hline \multicolumn{4}{|l|}{ Gender (\%) } \\
\hline Female & $10(83.3)$ & $11(91.7)$ & \multirow[t]{2}{*}{0.537} \\
\hline Male & $2(16.7)$ & $1(8.3)$ & \\
\hline \multicolumn{4}{|l|}{ Education (\%) } \\
\hline Diploma & $9(75)$ & $9(75)$ & \multirow[t]{2}{*}{1.000} \\
\hline Bachelor & $3(25)$ & $3(25)$ & \\
\hline \multicolumn{4}{|c|}{ Length of working (\%) } \\
\hline$<5$ year & $4(44.4)$ & $5(55.6)$ & \multirow[t]{2}{*}{0.673} \\
\hline 5-10 year & $8(53.3)$ & $7(46.7)$ & \\
\hline
\end{tabular}


Table 3: Comparison of mean MoCA-INA scores before and after provision of light

\begin{tabular}{|c|c|c|c|c|}
\hline Groups & $\begin{array}{l}\text { Initial MoCA-INA } \\
\text { average }\end{array}$ & $\begin{array}{l}\text { Final MoCA-INA } \\
\text { average }\end{array}$ & $\begin{array}{l}\text { Increase percentage of } \\
\text { MoCA-INA }(\%), \mathrm{Cl} 95 \%\end{array}$ & $\mathrm{p}$-value \\
\hline Treatment & $22.33 \pm 0.985$ & $27.33 \pm 0.888$ & $5.00(4.234-5.766)$ & $<0.001^{*}$ \\
\hline Control & $22.58 \pm 1.929$ & $23.00 \pm 1.414$ & $0.417(0.008-0.841)$ & 0.054 \\
\hline
\end{tabular}

An unpaired t-test is performed to determine the significance or effectiveness of giving blue light and white light to an increase in cognitive function scores. The average effectiveness of an increase in MoCAINA scores between the two groups was statistically significant $(p<0.001)$, the results of the analysis are shown in Table 4.

Table 4: Mean increase in MOCA-INA in the treatment groups and control groups

\begin{tabular}{lll}
\hline Groups & Increase percentage of MoCA-INA & p-value \\
\hline Treatment & $4.83 \pm 1.115$ & $<0.001^{*}$ \\
Control & $0.42 \pm 0.669$ & \\
\hline${ }^{*}$ Statistically significant. & &
\end{tabular}

The results of the Shapiro-Wilk test showed that the levels of orexin serum in the two groups were spread normally, and then a paired t-test was performed to assess the mean increase in serum orexin levels of each study group. The average results of the increase in serum orexin levels in the treatment group (1168.922 \pm $1305.12 \mathrm{pg} / \mathrm{ml} ; \mathrm{p}<0.001)$ were higher than the control group (336.704 $\pm 536.022 \mathrm{pg} / \mathrm{ml} ; \mathrm{p}=0.052)$. The results of data analysis are shown in Table 5.

\begin{tabular}{|c|c|c|c|c|}
\hline Groups & $\begin{array}{l}\text { Initial orexin serum } \\
\text { level average } \\
(\mathrm{pg} / \mathrm{ml})\end{array}$ & $\begin{array}{l}\text { Final orexin serum } \\
\text { level average } \\
(\mathrm{pg} / \mathrm{ml})\end{array}$ & $\begin{array}{l}\text { Increase of serum } \\
\text { orexin level (\%), Cl } \\
95 \%\end{array}$ & p-value \\
\hline \multirow[t]{2}{*}{ Treatment } & $3436.141 \pm$ & $4504.385 \pm$ & 1068.244 & $<0.001^{*}$ \\
\hline & 796.804 & 291.910 & $(624.623-1511.862)$ & \\
\hline \multirow{2}{*}{ Control } & $4254.726 \pm$ & $3918.021 \pm$ & 336.706 & 0.052 \\
\hline & 484.558 & 566.319 & $(677.278-3.866)$ & \\
\hline
\end{tabular}

Unpaired t-test was performed to increase the effectiveness of exposure to white light in increasing serum oxygen levels, obtained an increase in mean serum levels in the treatment group was greater than the control group with $p=0.002$. The results of the analysis are shown in Table 6.

Table 6: Average increased serum orexin levels in the treatment and control groups

\begin{tabular}{lll}
\hline Groups & Average increase of serum orexin level $(\mathrm{pg} / \mathrm{ml})$ & p-value \\
\hline Treatment & $1168.922 \pm 1305.129$ & $0.002^{*}$ \\
Control & $336.704 \pm 536.022$ & \\
\hline${ }^{*}$ Statistically significant. & &
\end{tabular}

\section{Discussion}

The basic characteristics of the study found more female sex than men; this is because the number of female employees is more overall than men who work as nurses. Both groups had education levels, age averages and cognitive function scores were almost the same. This result is comparable with the previous studies on shifting nurses, found that there were more female subjects than men, namely, 97 women and 3 men, the age of all research subjects was the age of being productive [10].

The mean scores of the initial cognitive functions of the two groups were almost the same. There was a decrease in the cognitive function scores on nurses who worked with the night shift system. The results of this study are in accordance with the previous studies conducted on 100-night shift nurses, found $69 \%$ of subjects with low MoCA-INA values and cognitive impairment [10]. Other previous studies were in line with the results of this current study, conducted research at Sanglah Hospital Denpasar with the results of a decrease in cognitive function scores on nurses with a shift work system [5], [8].

The decline in cognitive function also occurs in other professions that use the shift work system, in line research conducted at resident doctors in Sanglah General Hospital Denpasar, the results of cognitive impairment in the group experiencing sleep disturbances [11]. The group who received the night watch assignment for 5 days had a lower Kaufman adolescent and adult intelligence test score compared to doctors who were not on night duty [12].

The treatment given by getting exposure to blue light, this is based on the results of the previous studies that exposure to blue light can increase one's alertness better than exposure to yellow light [13]. Blue light can provide influence on the body in a shorttime and requires less energy to affect the circadian rhythm compared to other light, besides blue light is associated with low drowsiness and increased attention [14].

The previous research also found that subjects who received exposure to blue light had attention functions and were able to perform tasks better than subjects who received exposure to the light emitting diode [15].

The results of this study indicate that the mean increase in serum orexin levels was higher in the treatment group who received exposure to blue light compared to the control group who received exposure to white light. No previous similar studies were found regarding the results of increased orexin levels in subjects who had exposure to blue light and were associated with the higher scores for improving cognitive function scores. Some previous studies have resulted in a decrease of orexin levels in serum and cerebrospinal fluid in patients who experience sleep disorders, such as narcolepsy [16].

Orexin was originally known to be a neuromodulator that increases appetite. Orexin and orexin receptors in the body are affected by food intake and the orexin system as a whole is activated by starvation and its activity will decrease when a person feels too full [17], [18]. The results 
of this study indicate an increase in orexin levels and cognitive function scores after exposure to blue light, as in previous studies in animals that obtained results that orexin has a role in influencing cognitive function and regulation of blood pressure [19]. Orexin is known to play a role in increasing attention, alertness, and appetite and has an excitatory effect on arousal centers, which aims to maintain the quality of wakefulness [17], [18], [19], [20]. Changes in work professional sleep patterns using a rotational system are known to affect the frontal and prefrontal systems, affecting intellectual ability, working memory, and the ability to respond to a problem [21]. This study assessed orexin levels and cognitive function scores after subjects received exposure to blue light and similar studies had not been obtained before, but this study did not assess in detail the condition of body weight and body metabolism that affected the work of orexin and orexin receptors, and the assessment of cognitive function scores was not carried out details on each domain of cognitive function. Not only in nurses but also in all professional healthcare such as residents in Sanglah General Hospital with partial sleep deprivation significantly correlated with decreased cognitive function [22].

\section{Conclusion}

The results of this study found that the group has received a blue light for improved mean cognitive scores and a higher increase in serum levels of the group than those who had exposure to white light. Further research is needed to assess this in more detail, the effects of body weight, body metabolism, appetite, and increase in the mean serum orexin levels of cognitive function.

\section{References}

1. Bazil CW, Westwood AJ. Sleep disorders. In: Elan DL, Stephan AM, Lewis PR, editors. Merritt's Neurology. $13^{\text {th }}$ ed. Philadelphia, PA: Wolters Kluwer; 2016. p. 979-89.

2. O'Leary AL. Orexin and melanin-concentrating hormone neurons: A Hypothalamic interface for sleep and feeding regulation. Biosci Horiz. 2014;7:1-8. https://doi.org/10.1093/ biohorizons/hzu008

3. Wenyu H, Kathryn MR, Biliana M, Joseph B. Circadian rhythms, sleep, and metabolism. J Clin Investig. 2011;121(6):2133-41. https://doi.org/10.1172/jci46043

PMid:21633182

4. Martin A, Johanne R, Miroslav K. Evaluating potential spectral impacts of various artificial lights on melatonin suppression, photosynthesis, and star visibility. PLoS One. 2013;8(7):e67798. https://doi.org/10.1371/journal.pone.0067798 PMid:23861808

5. Yuliantry LI, Laksmidewi AA, Adnyana IM. Paparan Cahaya Biru memperbaiki Gangguan Fungsi Kognitif melalui Penurunan Kadar Melatonin Serum Pada perawat Kerja Gilir RSUP Sanglah Denpasar" (Tesis). Denpasar: Universitas Udayana; 2017. https://doi.org/10.29342/cnj.v3i1.101

6. Lauralee S. Human Physiology from Cells to Systems. $7^{\text {th }}$ ed. Canada: Brooks/Cole Cengage Learning; 2007. p. 229-31.

7. Hanartoaji P, Sylvia FL, Freddy A, Herqutanto. Gambaran fungsi kognitif pada perawat gilir di RS cipto mangunkusumo. Neurona. 2013;30(2):87-95.

8. Tersila AD, Laksmidewi AA, Oka Al. Kualitas Tidur Buruk Berkorelasi dengan Penurunan Fungsi Kognitif pada Perawat Gilir di Unit Rawat Inap A RSUP Sanglah Denpasar. Bandung: Disampaikan pada Continuing Medical Education on Neurology; 2016. https://doi.org/10.29342/cnj.v3i1.101

9. Moreno-Casbas MT, Ruzafa-Martines M, Rol MA, Madrid JA, Pinto AS, Gonzales-Maria E, Fuentelsaz-Gallego C. Sleepiness in Spanish nursing staff influence of chronotype and care unit in circadian rhythm impairment: Research protocol. J Adv Nurs. 2014;70(1):211-9. https://doi.org/10.1111/jan.12200 PMid:23834526

10. Kaliyaperumal D, Elango $Y$, Santhanakrishanan I. Effects of sleep deprivation on the cognitive performance of nurse working in shift. J Clin Diagn Res. 2017;11(8):CC01-3. PMid:28969117

11. Samatra DP, Kesanda IM, Adnyana IM, Widyadharma IP. The effect of partial sleep deprivation in decrease of cognitive function in resident doctors of Udayana university/Sanglah general hospital. Int J Sci Res. 2017;6(4):215-8.

12. Dula DJ, Dula NL, Hamrick C, Wood GC. The effect of working serial night shifts on the cognitive functioning of emergency physicians. Ann Emerg Med. 2001;38:152-5. https://doi. org/10.1067/mem.2001.116024

PMid: 11468610

13. Lehrl S, Gerstmeyer K, Jacob HJ, Frieling H, Henkel AW, Meyrer $\mathrm{R}$, et al. Blue light improves cognitive performance. Proc Manufact. 2007;114(4):457-60. https://doi.org/10.1007/ s00702-006-0621-4 PMid: 17245536

14. Lockley SW, Evans EE, Scheer FA, Brainard GC, Czeisler CA Aeschbach D. Short-wavelength sensitivity for the direct effects of light on alertness, vigilance, and the waking electroencephalogram in humans. Sleep. 2006;29(2):161-8. https://doi.org/10.1093/sleep/29.2.161 PMid:16494083

15. Bansal N, Prakash NR, Randhawa JS, Kalra P. Effect of blue light on cognitive performance. Int Res J Eng Techmol. 2017;4(6):2434-42

16. Nishimo S, Mignot E. Article reviewed: Plasma orexin a lower in patients with narcolepsy. Sleep Med. 2002;3:377-8. https://doi. org/10.1016/s1389-9457(02)00078-3

17. Hungs M, Mignot E. Hypocretin/Orexin, Sleep and Narcolepsy. Bioessays. 2001;23:397-408. https://doi.org/10.1002/bies.1058

18. Gao XB, Hermes G. Neural plasticity in hypocretin neurons: The basic of hypocretinergic regulation of physiological and behavioral function in animals. Front Syst Neurosci. 2015;9:142. https://doi.org/10.3389/fnsys.2015.00142 PMid:26539086

19. Sieminski M, Szypenbeji J, Partinen E. Orexin, sleep, and blood pressure. Curr Hypertens Rep. 2018;20(9):79. PMid:29992504

20. Lu BS, Zee PC. Neurobiology of sleep. Clin Chest Med. 
2010;31(2):309-18.

PMid:20488289

21. Rouch I, Wild P, Ansiau D, Marquie JC. Shiftwork experience, age and cognitive performance. Ergonomics. 2005;48(10):128293. https://doi.org/10.1080/00140130500241670
PMid: 16253945

22. Samatara P, Kesanda IM, Adynana IM, Widyawarma IP. The effect of partial sleep deprivation in decrease of cognitive function in resident doctors of udayana university/sanglah general hospital. Int J Sci Res 2017;4:215-8. 